\title{
Involvement of the small intestine in systemic mast cell disease
}

\author{
BRIAN B. SCOTT, G. J. HARDY, AND M. S. LOSOWSKY \\ From the University Department of Medicine and Department of Pathology, St James's Hospital, Leeds
}

SUMMARY A patient is reported with mast cell infiltration of the small intestine in the absence of the skin involvement characteristic of mast cell disease. She also had subtotal villous atrophy responsive to a gluten-free diet. Criteria for diagnosing mast cell disease of the small intestine are proposed. The literature of small intestinal mast cell disease is reviewed and the relationship to coeliac disease is discussed.

Mast cell disease or mastocytosis has been defined as '. . . chronic affections accompanied by specific infiltrations of mast cells into the skin or other tissue' (Sagher and Even-Paz, 1967). Mast cells are distinguished histologically by characteristic, metachromatic, cytoplasmic granules and special stains such as toluidine blue are recommended for their detection (Sagher and Even-Paz, 1967). The skin is nearly always involved and the characteristic rash is known as urticaria pigmentosa. Systemic involvement occurs in $10 \%$ of patients with mast cell disease; any organ may be involved, including the small bowel on rare occasions. There are only a very few well-documented reports of systemic mast cell disease in the absence of skin involvement (Mutter et al., 1963; Gonnella and Lipsey, 1964).

Mast cell infiltrations in the gastrointestinal tract have been demonstrated in a number of cases at necropsy (Sagher and Even-Paz, 1967) but detection during life is distinctly rare. One of the problems in diagnosis is a lack of agreed criteria for recognizing '. . . specific infiltrations of mast cells ...'

The present report describes a patient with typical symptoms of mast cell disease and mast cell infiltration of the small intestine but no skin involvement. In addition, there was subtotal villous atrophy and a response to a gluten-free diet, features described previously in association with mast cell disease. Studies are presented in which mast cells in the small bowel mucosa are quantitated in health and disease to enable criteria to be proposed for diagnosing mast cell disease at this site.

Received for publication 9 July 1975.

\section{Case Report}

The patient, a 47 year old housewife, became ill at the age of 28 years when she began to complain of bouts of colicky abdominal pain and diarrhoea. Sigmoidoscopy and radiology of the small and large bowel were normal. Symptoms persisted for 10 years after which she started to complain of flushing attacks lasting about 20 minutes and mainly affecting the face.

Further investigation at a second hospital showed intestinal malabsorption: faecal fat $56 \mathrm{mmol} / 24 \mathrm{~h}$, xylose absorption impaired, lactose tolerance curve flat; a barium follow-through examination showed non-specific features of malabsorption. Recurring features of intestinal obstruction suggested Crohn's disease and laparotomy was performed which showed a thickened, distended jejunum and small glands in the mesentery. Operative jejunal biopsy showed subtotal villous atrophy. A diagnosis of mast cell disease was considered and, although no skin changes were present and bone marrow examination was normal, confirmatory evidence was provided by a raised urinary histamine excretion. Urinary 5-HIAA excretion was repeatedly normal. Treatment with antihistamines gave some relief.

The patient continued to complain of recurrent attacks of abdominal pain, often with flushing, and was admitted to a third hospital for investigation. There was no blood eosinophilia, repeated faecal examinations for protozoa, cysts and acid-fast bacilli were negative, urinary histamine excretion varied from 1190 to $5230 \mu \mathrm{g} / 24 \mathrm{~h}$ (normal less than 2000), a $15 \mathrm{~g}$ histidine load was handled normally with no excess of histamine in the urine, urinary 
5-HIAA excretion was normal both in between (19 $\mu \mathrm{mol} / 24 \mathrm{~h})$ and during $(29 \mu \mathrm{mol} / 24 \mathrm{~h})$ attacks of pain, an oral load of 5-HT was handled normally with an expected increase in urinary 5-HIAA, urinary heparinoids were increased to 36 and $\mathbf{4 0}$ units/hour (normal 13-29), skin biopsy showed no excess of mast cells, bone marrow examination showed no mast cells or acid-fast bacilli, a small bowel enema showed fine and coarse nodules in the mucosa.

At a further laparotomy the bowel appeared normal but there were five enlarged glands at the root of the jejunal mesentery, one of which, after excision, was found to contain creamy pus. Operative small bowel biopsy showed partial villous atrophy and $\mathbf{3 0}$ mast cells/high-power field of the lamina propria (mean of 20 HPF). Liver histology was normal and no mast cells were seen. The lymph nodes showed irregular areas of necrosis containing much leucocyte debris. A zone of macrophages, lymphocytes

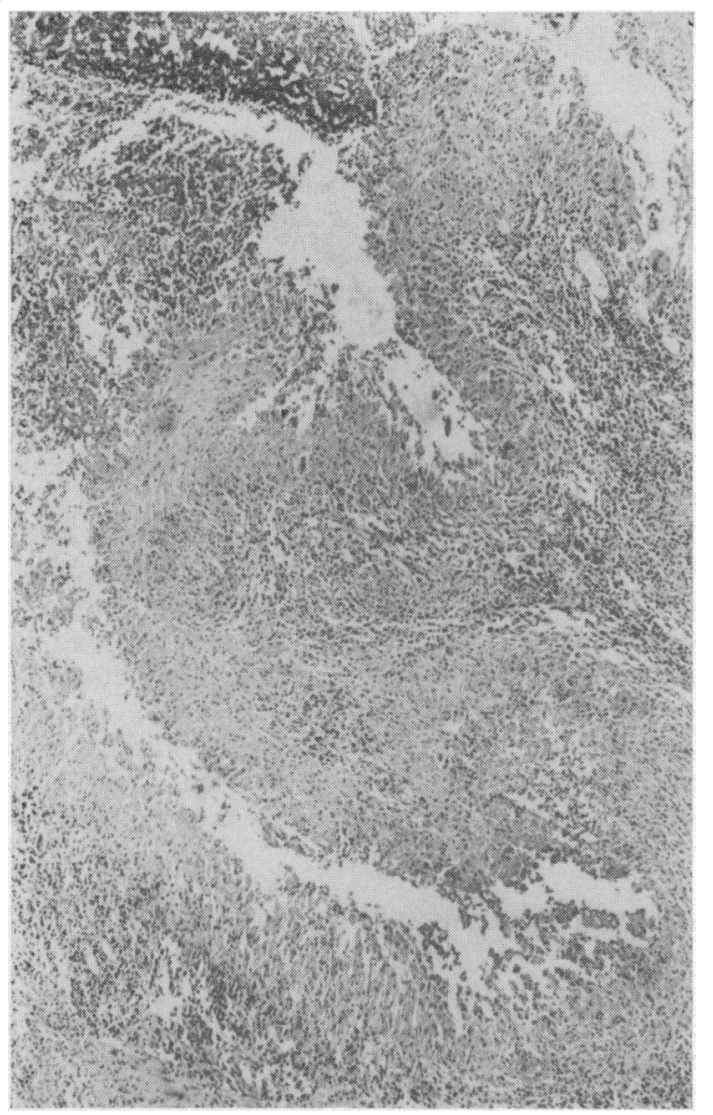

Fig. 1 Abdominal lymph node showing leucocyte debris (top right) in centre of granuloma. No microorganisms were demonstrable either histologically or on culture. $\times 45$. and plasma cells surrounded the necrotic areas, and occasional multinucleate macrophages were seen (Fig. 1). No bacteria were demonstrated in thelesions, either by Gram staining or by the Ziehl-Neelsen technique, and stains for fungi were negative. She was given one year's antituberculous therapy with streptomycin and Pasinah D.

Although she gained weight, she continued to complain of recurrent abdominal pain and distension and further investigation was undertaken. Malabsorption persisted: faecal fat $53 \mathrm{mmol} / 24 \mathrm{~h}$, the glucose tolerance curve was flat, the lactose tolerance curve was flat, xylose absorption was impaired. A $15 \%$ eosinophilia had developed but this disappeared after antituberculous therapy was stopped. A 16-day trial of $40 \mathrm{mg}$ prednisone daily effected no improvement. A gluten-free diet was tried but was found disagreeable and was stopped after three weeks. She was then discharged home taking propantheline, antihistamines and analgesics and she became chronically constipated. Further investigation at a fourth hospital three years after the first laparotomy showed persistent malabsorption (faecal fat $42 \mathrm{mmol} / 24 \mathrm{~h}$ ). The Mantoux test was negative at 1/1000 PPD tuberculin. A significant disturbance of colonic motility was found and selfadministered intramuscular hyoscine was advised with good effect.

Attacks of abdominal pain continued and nine years after the first laparotomy she developed recurrent severe abdominal pain requiring regular pethidine and was readmitted to a fifth hospital. Steatorrhoea had diminished to $25 \mathrm{mmol} / 24 \mathrm{~h}$. It was considered that social and emotional problems were largely responsible for her symptoms.

FINAL INVESTIGATIONS

A few months later she was referred to this department. She was taking the following drugs: diazepam, imipramine, sodium amytal, hyoscine, Dorbanex and Doloxene. She looked well and abdominal examination showed no significant abnormality. The results of investigations were as follows (normal values in parentheses):

\section{Haematology}

$\mathrm{Hb} 11.5 \mathrm{~g} / \mathrm{dl}$, white cell count 8100 per $\mathrm{cmm}$ with a normal differential count, a blood film showed mild macrocytosis and slight hypochromia, the ESR was $50 \mathrm{~mm}$ in one hour, serum iron $11 \mu \mathrm{mol} / 1$ (11-33), iron-binding capacity $65 \mu \mathrm{mol} / \mathrm{l}$ (54-80), serum folate $0 \cdot 8 \mu \mathrm{g} / \mathrm{l}(3 \cdot 0-12 \cdot 0)$, red cell folate $153 \mu \mathrm{g} / \mathrm{l}(160-320)$, serum $B_{12} 105 \mathrm{ng} / \mathrm{l}(>110)$, prothrombin time 12 $\mathrm{s}$ (control $12 \mathrm{~s}$ ).

\section{Biochemistry}

Serum albumin $44 \mathrm{~g} / 1$ (37-49), serum calcium 2.31 


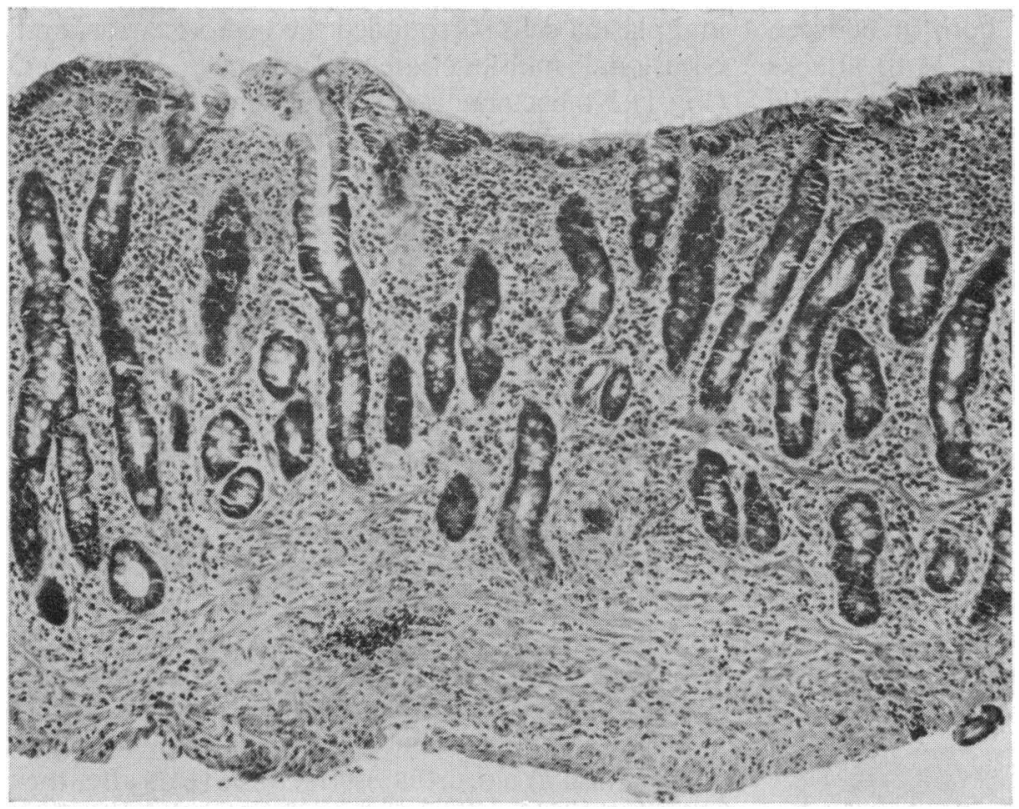

Fig. 2 Jejunal biopsy taken just before treatment with a gluten-free diet from $20 \mathrm{~cm}$ past the duodenojejunal junction showing subtotal villous atrophy and disorganized surface epithelium. $\times 30$.

$\mathrm{mmol} / 1$ (2.25-2.60), serum alkaline phosphatase 8.7 KA units (4-13), plasma carotene $1.93 \mu \mathrm{mol} / \mathrm{l}$ (>0.74).

\section{Tests of Absorption}

Glucose tolerance test (blood gluccse levels before and at 30 -min intervals following $50 \mathrm{~g}$ oral glucose) $4 \cdot 4,4 \cdot 7,6 \cdot 1,4 \cdot 4,5 \cdot 5 \mathrm{mmol} / 1 ; 60 \%$ of a $5 \mathrm{~g}$ dose of xylose was excreted in the urine in five hours (> $23 \%$ ); Schilling test with intrinsic factor, $5.6 \%$ of oral ${ }^{58} \mathrm{Co}$ vitamin $\mathrm{B}_{12}$ appeared in the urine in $24 \mathrm{~h}(>12 \%)$; urinary indican $0.41 \mathrm{mmol} / 24 \mathrm{~h}$ (< 0.47$)$; two-day faecal fat $25 \mathrm{mmol} / 24 \mathrm{~h}(<18)$; dietary fat $100 \mathrm{~g} / 24 \mathrm{~h}$.

\section{Small bowel biopsy}

With the peroral hydraulic instrument (Flick et al., 1961) three biopsies each were taken from the second part of the duodenum, $5 \mathrm{~cm}$ past the duodenojejunal junction, and $20 \mathrm{~cm}$ past the duodenojejunal junction. All showed a flat mucosa on dissecting microscopy and all showed subtotal villous atrophy on histology (Fig. 2). The surface epithelium was cuboidal with haphazardly situated nuclei and increased interepithelial lymphocytes. There were two eosinophils/HPF of the lamina propria (mean of $20 \mathrm{HPF}$ ). Toluidine blue staining showed 30 mastcells/HPF (mean of 20HPF) (Fig. 3).

\section{Immunology}

HL-A type-HL-Al, HL-A8, W18; immunoglo- bulins IgG $15 \cdot 01 \mathrm{~g} / 1(8 \cdot 0-18 \cdot 0)$, IgA $2 \cdot 74 \mathrm{~g} / 1(0 \cdot 9-4 \cdot 5)$, $\operatorname{IgM} 1.56 \mathrm{~g} / 1(0.5-2.5)$, serum gluten antibodies by tanned red cell test 1/1028, milk antibodies $1 / 256$; no serum autoantibodies were detected by the indirect tissue immunofluorescent technique; the Mantoux test was negative at 1/1000 PPD tuberculin.

\section{Radiology}

A chest radiograph was normal as was a skeletal survey.

She was treated only with a gluten-free diet and within two weeks she reported symptomatic improvement. After three months, small bowel biopsies, taken from the same sites as,previously, showed a marked improvement with partial villous atrophy and regular, columnar epithelial cells (Fig. 4), the improvement being most marked in the distal specimens. The mast cell content, however, had not altered, there being 30 per HPF (mean of $90 \mathrm{HPF}$ in nine biopsies).

\section{Criteria for Small Intestinal Mast Cell Disease}

Normal human skin contains 1-2 mast cells per HPF (Kallman, 1960; Lese, 1962) which may be increased up to threefold in chronic inflammatory states (Lese, 1962). The finding of more than 6 mast cells per HPF should strongly suggest mast cell disease at that site (Sagher and Even-Paz, 1967). There is less information about other organs but Norris et al. (1963) in a necropsy study of the 


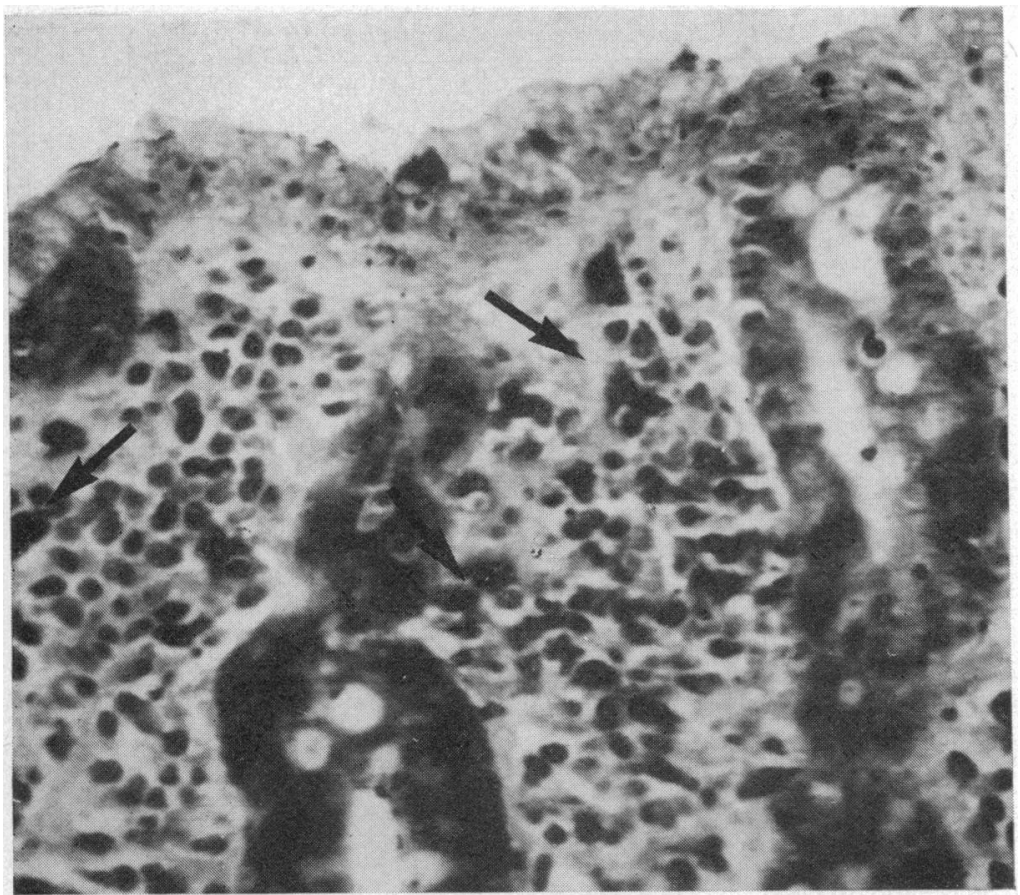

Fig. 3 Lamina propria of jejunal mucosa stained with toluidine blue. Mast cells are indicated by arrows. $\times 375$.

gastrointestinal tract of a 30 year old negress dying of active rheumatic heart disease showed that mast cell numbers varied both according to the level and the layer. In the jejunum there were
2 mast cells per HPF of the mucosa, 4.5 per HPF of the submucosa, 2.5 per HPF of the muscularis mucosae, and 2 per HPF of serosa.

We have studied peroral biopsies of jejunum from

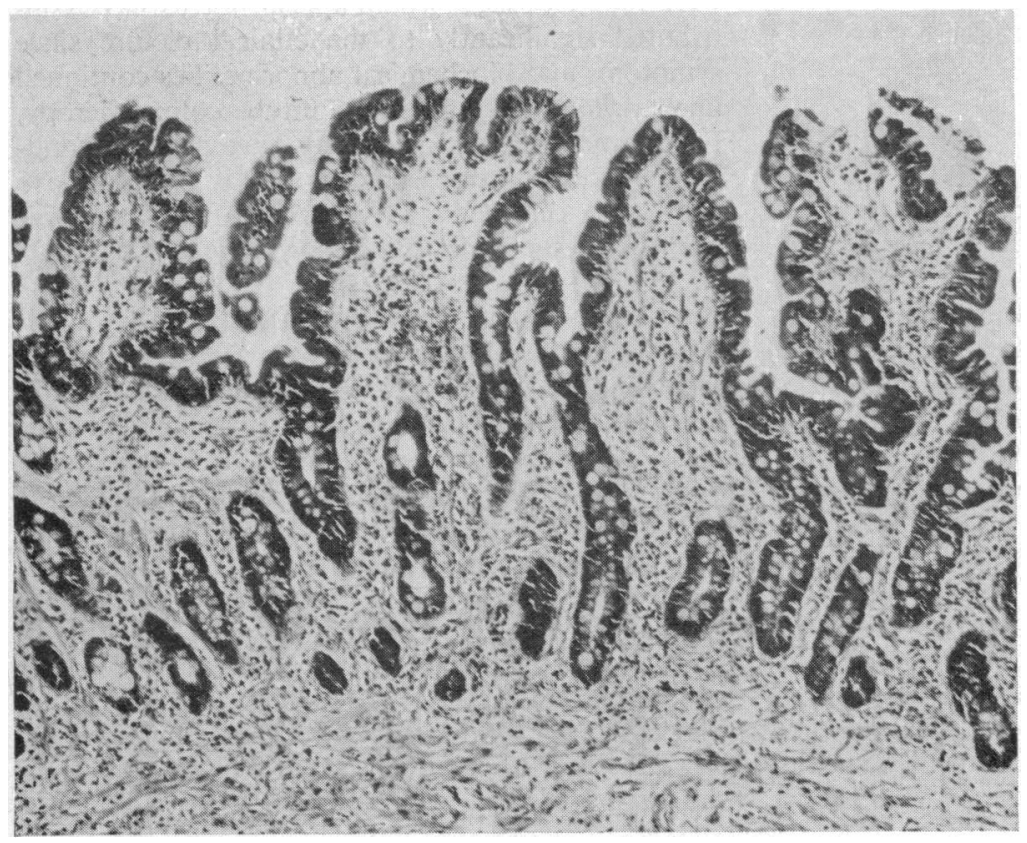

Fig 4. Jejunal biopsy taken after three months' treatment with a gluten-free diet from $20 \mathrm{~cm}$ past the duodenojejunal junction showing partial villous atrophy a definite improvement (cf Fig. 2) $\times 30$. 


\begin{tabular}{|c|c|c|c|c|c|}
\hline Diagnosis & Age & Sex & Biopsy Appearance ${ }^{1}$ & Mast Cells per $H P F^{2}$ & No. of HPF Counted \\
\hline $\begin{array}{l}\text { Coeliac disease (normal diet) } \\
\text { Coeliac disease (normal diet) } \\
\text { Coeliac disease (normal diet) } \\
\text { Coeliac disease (normal diet) } \\
\text { Coeliac disease (normal diet) } \\
\text { Coeliac disease (normal diet) } \\
\text { Coeliac disease (normal diet) } \\
\text { Coeliac disease (normal diet) } \\
\text { Coeliac disease (normal diet) } \\
\text { Coeliac disease (normal diet) } \\
\text { Coeliac disease (normal diet) }\end{array}$ & $\begin{array}{l}41 \\
30 \\
39 \\
35 \\
35 \\
39 \\
62 \\
33 \\
19 \\
36 \\
17\end{array}$ & $\begin{array}{l}\mathbf{F} \\
\mathbf{F} \\
\mathbf{M} \\
\mathbf{F} \\
\mathbf{F} \\
\mathbf{F} \\
\mathbf{F} \\
\mathbf{M} \\
\mathbf{F} \\
\mathbf{F} \\
\mathbf{F}\end{array}$ & Mean & $\begin{array}{l}2 \cdot 6 \\
4 \cdot 0 \\
1 \cdot 2 \\
1 \cdot 3 \\
3 \cdot 5 \\
1 \cdot 1 \\
0 \cdot 5 \\
1 \cdot 1 \\
1 \cdot 1 \\
1 \cdot 1 \\
2 \cdot 5 \\
1 \cdot 8\end{array}$ & $\begin{array}{r}10 \\
6 \\
20 \\
20 \\
14 \\
10 \\
14 \\
20 \\
14 \\
7 \\
20 \\
14\end{array}$ \\
\hline $\begin{array}{l}\text { Irritable colon syndrome } \\
\text { Irritable colon syndrome } \\
\text { Irritable colon syndrome } \\
\text { Irritable colon syndrome } \\
\text { Irritable colon syndrome } \\
\text { Irritable colon syndrome } \\
\text { Irritable colon syndrome } \\
\text { Irritable colon syndrome } \\
\text { Irritable colon syndrome } \\
\text { Unexplained anaemia }\end{array}$ & $\begin{array}{l}32 \\
46 \\
41 \\
38 \\
49 \\
52 \\
52 \\
50 \\
15 \\
55\end{array}$ & $\begin{array}{l}\mathbf{F} \\
\mathbf{M} \\
\mathbf{F} \\
\mathbf{M} \\
\mathbf{F} \\
\mathbf{F} \\
\mathbf{F} \\
\mathbf{F} \\
\mathbf{F} \\
\mathbf{F}\end{array}$ & Mean & $\begin{array}{l}3.7 \\
4.1 \\
1.9 \\
2.2 \\
2.1 \\
1.4 \\
1.5 \\
1.8 \\
3.5 \\
0.2 \\
2.3\end{array}$ & $\begin{array}{l}16 \\
14 \\
16 \\
16 \\
16 \\
16 \\
20 \\
20 \\
16 \\
20 \\
17\end{array}$ \\
\hline
\end{tabular}

Table 1 Numbers of mast cells per HPF of lamina propria in peroral jejunal biopsies

1SVA $=$ subtotal villous atrophy, $\mathrm{N}=$ normal, PVA $=$ partial villous atrophy. ${ }^{2}$ One $\mathrm{HPF}=$ approximately $0 \cdot 2 \mathrm{mn} .{ }^{3}$.

11 patients with untreated coeliac disease and 10 controls without evidence of small bowel disease. The numbers of mast cells in the lamina propria are shown in Table 1. The average number of mast cells in both groups was 2 per HPF. Thus by analogy with the findings in the skin we would tentatively suggest that the demonstration of more than 6 mast cells per HPF in the lamina propria of jejunal biopsies is suggestive of mast cell disease.

\section{Discussion}

\section{PRESENT CASE}

The following features all support a diagnosis of mast cell disease in this patient: (1) histaminuria, (2) typical flushing attacks, (3) recurrent gastrointestinal symptoms, (4) typical barium contrast radiological appearance of the small intestine, (5) increased urinary heparinoids, and (6) increased mast cells in the small bowel mucosa. Against this diagnosis is the absence of skin involvement, which, although extremely rare, has been described in mast cell disease.

In addition, there was subtotal villous atrophy of the small bowel mucosa and surface epithelial changes typical of coeliac disease with improvement following treatment with a gluten-free diet, thus establishing a diagnosis of coeliac disease. Other features of coeliac disease were raised levels of gluten antibodies (Taylor et al., 1964) and the presence of HL-A8 (Falchuck et al., 1972; Stokes et al., 1973).
The nature of the granulomatous condition of the abdominal lymph node is not clear.If this were active tuberculosis, one would expect detection of the tubercle bacillus either on microscopy or culture. A positive Mantoux test would also be expected although intestinal tuberculosis with a negative test has been reported (Fung et al., 1970). Even if it were tuberculosis, it would appear not to have contributed significantly to the clinical picture since symptoms and biochemical abnormalities continued unchanged during and after antituberculous therapy. Furthermore, tuberculosis may have arisen secondary to intestinal disease since similar patients have depressed cell-mediated immunity and negative Mantoux tests (Scott and Losowsky, 1974).

\section{REPORTED CASES OF SMALL INTESTINAL} MAST CELL DISEASE

Jarnum and Zachariae (1967) and Clemett et al. (case III, 1968) each described a single patient with mast cell disease, mast cell infiltration in the lamina propria of the small bowel, and normal villi. Three patients with mast cell disease and partial villous atrophy are described, one had a 'large' increase in mast cells (Clemett et al., 1968, case I), another (Bank and Marks, 1963), in whom mast cells did not appear excessive, had an eosinophilic infiltration which is a feature suggestive of mast cell infiltration (Sagher and Even-Paz, 1967); and the third (Goldgraber, 1963) had an increase of round cells in the lamina propria, which were thought to be mast 
cells. Rubin and Dobbins (1965) reported a patient with subtotal villous atrophy of the small bowel but no increase in mast cells and Broitman et al. (1970) reported a patient (also reported by Fitzpatrick, 1961; Janower, 1962; Clemett et al., 1968) with subtotal villous atrophy but no increase in mast cells although eosinophils were increased and increased mast cells had been previously demonstrated in the submucosa. Interestingly, both patients responded clinically and histologically to a glutenfree diet and must therefore be considered to have coeliac disease. Furthermore, there is another patient who probably also had systemic mast cell disease and coeliac disease (Lees and Stroud, 1959) although histological details were not given. All of the above patients were said to have typical urticaria pigmentosa except the patient of Rubin and Dobbins (1965) in whom this is presumed.

\section{RELATIONSHIP TO COELIAC DISEASE}

The association of coeliac disease with mast cell disease, now reported in four patients, would seem to be more than fortuitous. Moreover it is possible that three additional patients (Bank and Marks, 1963; Goldgraber, 1963; Clemett et al., 1968, case I) also had coeliac disease since they had partial villous atrophy but without demonstrated responses to a gluten-free diet.

The possiblity that mast cell infiltration is a result of gluten sensitivity is unlikely in view of (1) the mast cell content not altering after treatment with a gluten-free diet and (2) the absence of mucosal mast cell infiltration in patients with untreated, uncomplicated coeliac disease. The other possibility, that mast cell infiltration predisposes to gluten sensitivity, cannot be refuted in the present state of knowledge, but immunological mechanisms are almost certainly involved in the mucosal damage of coeliac disease and mast cells have a role in some immunological reactions, especially type I reactions involving IgE. It is of interest that Shiner (1973) has demonstrated a 'slight to moderate' infiltration of mast cells after gluten challenge in coeliac children and after milk challenge in a child with cow's milk allergy (Shiner et al., 1975). Other mechanisms must, however, also operate in view of (1) patients with mucosal mast cell infiltration and normal villi (Jarnum and Zachariae, 1967; Clemett et al., 1968, case III) and (2) patients with subtotal villous atrophy but no demonstrated increase in mast cells at that site (Rubin and Dobbins, 1965; Broitman et al., 1970).

\section{RADIOLOGY}

A characteristic barium contrast radiological appearance of the small bowel in systemic mast cell disease has been described (Janower, 1962; Remy, 1962; Clemett et al., 1968; Jarnum and Zachariae, 1967). This consists of diffuse thickening of the bowel wall and multiple nodular filling defects similar to the appearance of nodular lymphoid hyperplasia. It is not clear whether the nodules represent mast cell infiltrates or 'urticaria' of the small bowel mucosa.

\section{MALABSORPTION AND MAST CELL DISEASE}

Malabsorption in mast cell disease might arise from either mucosal infiltration by mast cells, coincidental coeliac disease, or from the disturbance of gastrointestinal motility produced by histamine or other chemicals released from mast cells. Although diarrhoea and other abdominal complaints are common in all forms of mast cell disease, malabsorption has been documented in only seven patients (Table 2). There are other patients described with diarrhoea suggestive of malabsorption (Ellis, 1949; AsboeHansen, 1960) but without adequate documentation.

\section{PROGNOSIS AND TREATMENT}

The effect of small intestinal involvement on the prognosis of mast cell disease is not clear in view of the paucity of recorded cases. However, systemic

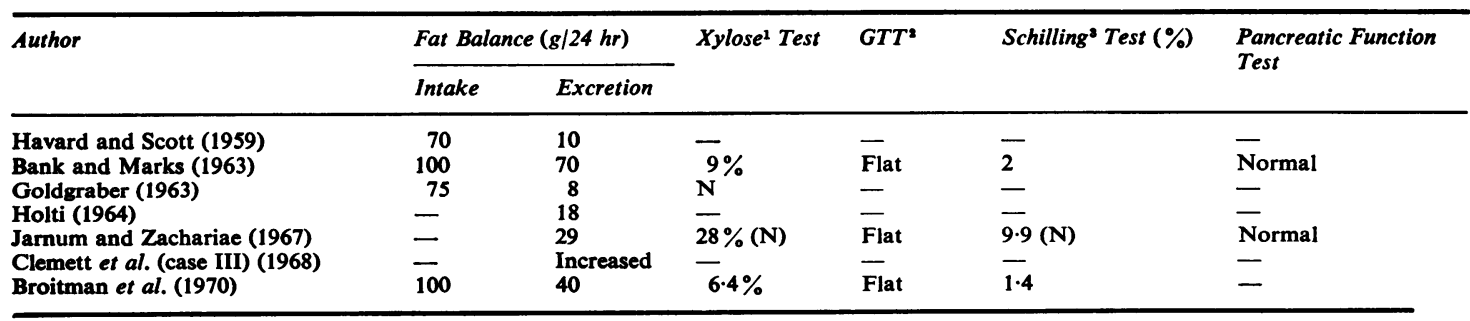

Table 2 Reported cases of mast cell disease and malabsorption

'Percentage of $25 \mathrm{~g}$ oral xylose appearing in urine in five hours.

Glucose tolerance test.

Percentage of oral labelled $B_{12}$ appearing in urine in 48 hours. 
mast cell disease generally may spontaneously improve, although one-third of patients proceed to a fatal termination, commonly from leukaemia but also from the complications of peptic ulcer or liver involvement.

Treatment is aimed at reducing the amount of histamine produced by mast cells. Antihistamines (Sagher and Even-Paz, 1967), histidine decarboxylase inhibitors (Levine, 1960), and oral sodium cromoglycate (Dolovich reported by Kingsley, 1974) may all be effective. Steroids are occasionally beneficial but unsatisfactory results have been recorded by a number of authors (Sagher and Even-Paz, 1967). Avoidance of stimuli to mast cell histamine release should be advised-for example, codeine, aspirin, alcohol, allergens, extremes of heat and cold, trauma and radiation.

\section{References}

Asboe-Hansen, G. (1960). Urticaria pigmentosa with generalized tissue mastocytosis and blood basophilia. Archives of Dermatology, 81, 198-202.

Bank, S., and Marks, I. N. (1963). Malabsorption in systemic mast cell disease. Gastroenterology, 45, 535-549.

Broitman, S. A., McCray, R. S., May, J. C., Deren, J. J., Ackroyd, F., Gottlieb, L. S., McDermott, W., and Zamcheck, N. (1970). Mastocytosis and intestinal malabsorption. American Journal of Medicine, 48, 382-389.

Clemett, A. R., Fishbone, G., Levine, R. J., James, A. E., and Janower, M. (1968). Gastrointestinal lesions in mastocytosis. American Journal of Roentgenology, 103, 405-412.

Ellis, J. M. (1949). Urticaria pigmentosa. Archives of Pathology, 48, 426-435.

Fitzpatrick, T. B. (1961). Urticaria pigmentosa with smallbowel involvement. Archives of Dermatology, 83, 515.

Falchuck, Z. M., Rogentine, G. N., and Strober, W. (1972). Predominance of histocompatibility antigen HL-A8 in patients with gluten-sensitive enteropathy. Journal of Clinical Investigation, 51, 1602-1605.

Flick, A. L., Quinton, W. E., and Rubin, C. E. (1961). A peroral hydraulic biopsy tube for multiple sampling at any level of the gastrointestinal tract. Gastroenterology, 40, 120-127.

Fung, W. P., Tan, K. K., Yu, S. F., and Kho, K. M. (1970). Malabsorption and subtotal villous atrophy secondary to pulmonary and intestinal tuberculosis. Gut, 11, 212-216.

Gonnella, J. S., and Lipsey, A. I. (1964). Mastocytosis manifested by hepatosplenomegaly. New England Journal of Medicine, 271, 533-535.
Goldgraber, M. B. (1963). Steatorrhoea: a clinical-pathologic correlation. Israel Medical Journal, 22, 156-175.

Havard, C. W. H., and Scott, R. B. (1959). Urticaria pigmentosa with visceral and skeletal lesions. Quarterly Journal of Medicine, 28, 459-470.

Holti, G. (1964). Reported by Sagher, F., and Even-Paz, Z. (1967). Mastocytosis and the Mast Cell. Karger, Basel.

Janower, M. L. (1962). Mastocytosis of the gastrointestinal tract. Acta Radiologica (Stockholm), 57, 489-493.

Jarnum, S., and Zachariae, H. (1967). Mastocytosis (urticaria pigmentosa) of skin, stomach, and gut with malabsorption. Gut, 8, 64-68.

Kallman, S. (1960). In Discussion by J. Meyers. Urticaria pigmentosa. Archives of Dermatology, 81, 161-162.

Kingsley, P. J. (1974). Oral sodium cromoglycate in gastrointestinal allergy. Lancet, 2, 1011.

Lees, M. H., and Stroud, C. E. (1959). Bone lesions of urticaria pigmentosa in childhood. Archives of Diseases in Childhood, 34, 205-209.

Lese, L. (1962). Urticaria pigmentosa. Archives of Dermatology, 85, 419-420.

Levine, R. J. (1966). Histamine synthesis in man: inhibition by 4-bromo-3-hydroxybenzyloxyamine. Science, 154, 1017-1019.

Mutter, R. D., Tannenbaum, M., and Ultmann, J. E. (1963). Systemic mast cell disease. Annals of Internal Medicine, 59, 887-906.

Norris, H. T., Zamcheck, N., and Gottlieb, L. S. (1963). The presence and distribution of mast cells in the human gastrointestinal tract at autopsy. Gastroenterology, 44, 448-455.

Remy, D. (1952). Gewebsmastzellen und MastzellenReticulose. Ergebnesse der Innerin Medizin und Kunderheilkunde, 17, 132-189.

Rubin, C. E., and Dobbins, W. O. (1965). Peroral biopsy of the small intestine-a review of its diagnostic usefulness. Gastroenterology, 49, 676-697.

Sagher, F., and Even-Paz, Z. (1967). Mastocytosis and the Mast Cell. Karger: Basel.

Scott, B. B., and Losowsky, M. S. (1974). Evidence suggesting depression of cell mediated immunity in coeliac disease. In Coeliac Disease, pp. 263-264. Edited by W. Th. J. M. Hekkens and A. S. Peña, Stenfert Kroese: Leiden.

Shiner, M. (1973). Ultrastructural changes suggestive of immune reactions in the jejunat mucosa of coeliac children following gluten challenge. Gut, 14, 1-12.

Shiner, M., Ballard, J., and Smith, M. E. (1975). The smallintestinal mucosa in cow's milk allergy. Lancet, 1, 136-140.

Stokes, P. L., Asquith, P., Holmes, G. K. T., Mackintosh, P., and Cooke, W. T. (1973). Inheritance and influence of histocompatibility (HL-A) antigen in adult coeliacs disease. Gut, 14, 627-630.

Taylor, K. B., Truelove, S. C., and Wright, R. (1964). Serologic reactions to gluten and cow's milk proteins in gastrointestinal disease. Gastroenterology, 46, 99-108. 